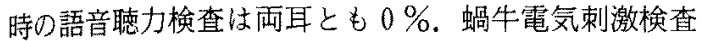
は者耳く左耳で良好. CT および MRI で蜡牛の骨化は みとめられず，螖牛のリンパ液信号が検出された。 89 年10月19日左耳に人工内耳電極植え込み手術が行われ た，透析ではへパリンの代わりにFUT-175を使用し た. 出血音は $126 \mathrm{cc}$ と通常の症例に比べて 2 倍近い出 血量であった。

術後経過 術後経過は良好であり, 術後19力月経過 したが，局所の感染や異物反応はす心゙て認められてい ない.

語音聴取能 聴取のみで母音弁別能 $90 \%$ ，子音弁別
能34\%, 䫓律要素の弁別ははぼ100\%であつた。聴取十 読話では舟音弁別能 $100 \%$, 子音弁別能 $71 \%$, 文章反復 テストは15文節/分と他の症例に比して大きな差がな く，読話併用で日常会話が可能であり，簢単なことば は人工内耳による聴取のみで可能となった。手術前に 主として用いていた筆談を使用する必要はほとんどな くなった。

考案 本症例は聴賞障害に加之て血液透析という重 複障害をもつたケースである。この症例の成功安踏ま えて，今後，このような重複障寒例についても少しず つ適応を搪大してゆけるものと考える。

\title{
257.アブミ骨上部構造消失例の病態
}

\section{森山宽・本多芳男 (慈大)}

鼓室形成術においてIII型変法にするかIV型変法とな るかは，術後の聴力の改善に大きく影響するため，ア ブミ骨上部構造の有無は臨床的に重要な問題である。 アブミ骨とくに上部構造の消失はどの上うな病態で惹 起されるのか，過去の手術症例よりアブミ骨の状態を 検討してみた。対象とした症例は16歳以上の初回手術 例で，弛緩部真珠腄（鼓膜緊張部に穿孔や瘾着などの ない例) 75耳, 緊張部型真珠腫34耳, 前真珠腫(緊張 部型真珠堙と瘜着性中耳炎の中間型）20耳，瘜着性中 耳炎48耳，単純性穿孔性中耳炎266耳である。またアブ ミ骨の破壊の程度を 1) 破壊なし(正常)，2）小頭 のみの消失，3）脚の部分消失，4）上部構造の全消 失，に分け検討した。

アブミ骨の破壊は繁張部型真珠腫で73.5\%（上部構 造全消失例は $55.9 \%$ )，癒着性中耳炎で $39.7 \%$ (全消失 $14.6 \%$ となっており, 鼓室後上部の病変程度と比例 寸る。一方，弛緩部型真珠腫では真珠腫上皮が tympanic isthmusをこえて中吱室に進展しているも の以外はアブミ骨の破壊は原則としてみられない（ア ブミ骨の破壊17.3\%)。単純性穿孔性中耳炎に扔いて は、わずか4.4\%になんらかのアブミ骨の破壊をみるの みであり，通常は耳小骨の可動障害を認める頻度の方 が高い。またアブミ骨上部構造全消失例に执ける手術 時年莓は，アブミ骨正常例におけるそれよりも若く， 上部構造の消失と霍病期間の間に関係は諗められなか
つた４0歳以上の例において上部構造全消失例とアブ ミ骨正常例の骨導聴力を比較してみると，明ら加に全 消失例すなわち内耳突に病変のある群に骨導聴力の低 下在認めた。内耳空の病変に年蔽的な因子(罡病期間) が加味されることにより内耳障害が薏起されることが 推測された。質問 池田 稔(日大). 1) stapes 周 囲の硬化あるいは肉芽病変が高度で stapes 病変を確 認できなかった症例は統計上どのように取り扱った か. 2) stapes 周用の病変の処理をどこ末で行うか. 応答 アブミ骨周囲门硬化物質を可及的除去し確認 寸るが，それが不可能なものは統計から除いてある。 また second stageのときにアブミ骨周囲を清掃して 病変程度を確認したものは統計に入れてある。質 問大谷端(福鼠医大)。上部構造消失例の方加低年 齢であったようだが，上部構造消失例と非消失例との 間に年齢差はなかったか。応答 平均值のみでな く，分布状況より見ても，正常例よりもアブミ骨上部 構造消失例の方が莣干若い印象をうける。つまり罹病 期間が長いためにアブミ骨が破壤されるのではなく， 病変の强さに影響されると考える。質問 牧野邦彦(神户大)。アブミ骨周囲の肉芽の性状が，緊 㖘部真珠腫前真珠腫, 痣着性中耳炎で差があったか。 応答繁張部型真珠腫や前真珠腫では，アブミ骨周 进に炎症性肉芽が多く，虑着性中耳炎では線維性肉芽 が多く見られる傾向にある。

\section{8. 中耳腔気圧外傷と潜水} 耳抜きについて—

\section{大久保 仁・奥野秀次 - 石川紀彦・佐藤玲子、合津和央（東医歯大）}

最近のレジャースポーツとして人気のあるスクーバ ダイビング等の気圧外傷例が増加している。最近の 2 年間に133人の潜水を契機とした気圧外第が外来を訪
れた。患者は，成人男性 82 名，成人女性51名で年齢構 成の平均怯, 男性 $35.9 \pm 9.8$ 歳で, 女性は， $27.5 \pm 8.7$ 歳である。これらで聴力障害を認奴た者は, 伝㫮難聴 